\title{
Tree Trimmer is Struck and Killed by Falling Tree Limb
}

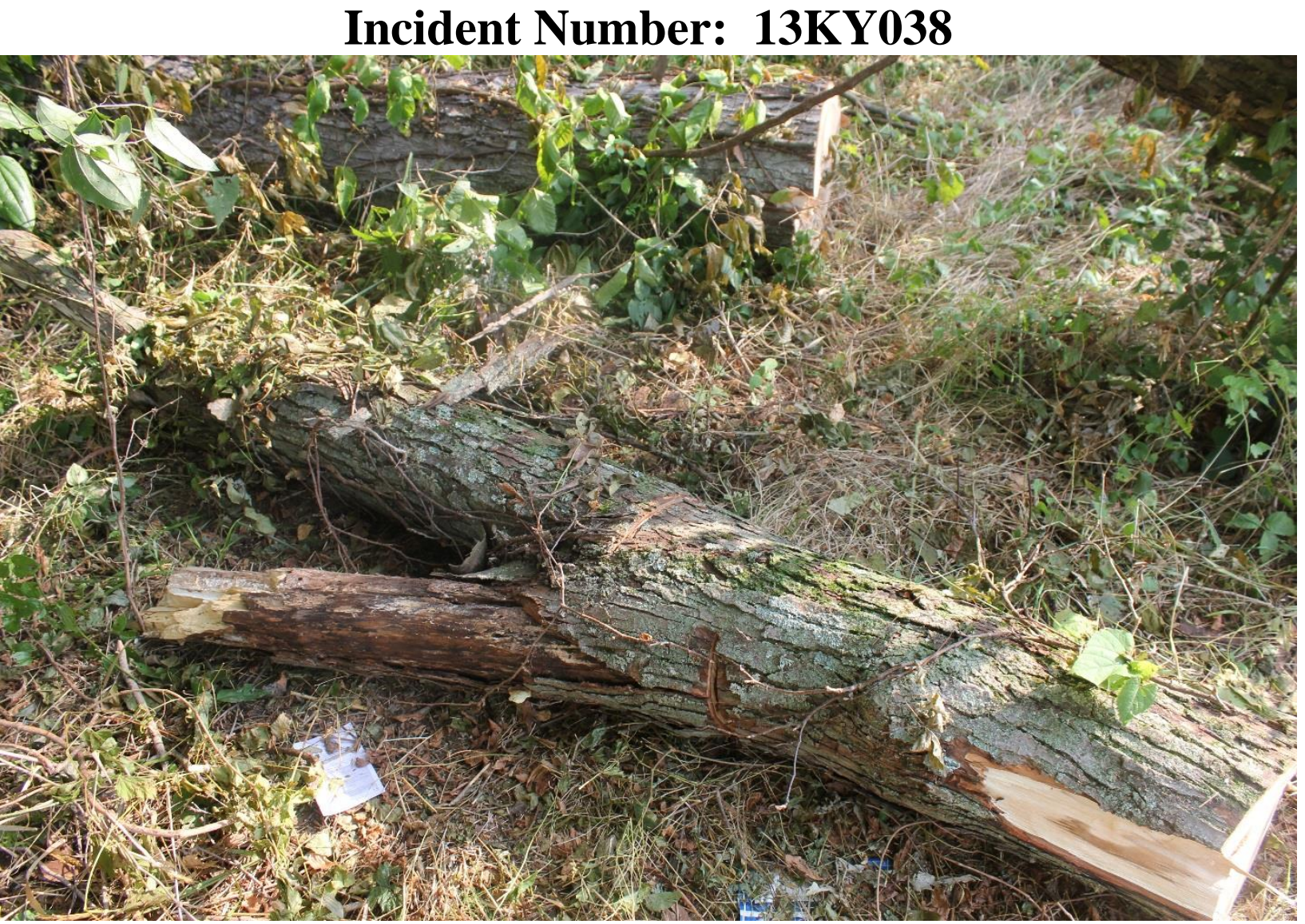

Photo courtesy of KY OSHA

Kentucky Fatality Assessment and Control Evaluation Program Kentucky Injury Prevention and Research Center 333 Waller Avenue

Suite 242

Lexington, Kentucky 40504

Phone: 859-323-2981

Fax: 859-257-3909

www.kiprc.uky.edu

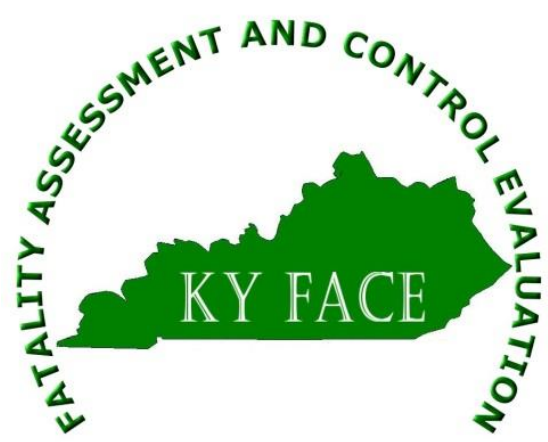




\section{Kentucky Fatality Assessment and Control Evaluation (FACE) Program Incident Number: 13KY038 \\ Release Date: January 9, 2015 \\ Subject: Tree Trimmer is Struck and Killed by Falling Tree Limb}

\section{Introduction}

September 7, 2013, at 1:25 p.m., a 52-year-old tree trimmer and married father of four, was attempting to clear a tree that was lying on a telephone line. The tree section that was in contact with the telephone line was a "fork" which was two extensions off the main trunk of the tree. Using a Stihl HT 101 pole saw, the victim made two cuts on the right fork, a cut on the left fork, then two more cuts on the left fork but could not saw through the limb. The victim attempted to make another cut on the inside left fork, when the pole saw he was using became stuck. When the victim and a co-worker pulled on the pole saw, their hard hats fell off, and they did not put them back on. The victim used a Stihl MS 170 chain saw retrieved from the truck and sawed through the main trunk of the tree that caused the left fork section to drop and strike the victim in the face and head. The co-worker did not witness the victim being struck, but found him lying with a 9 foot section of the tree limb on him, bleeding from his nose and mouth. The co-worker called 911 and emergency crews responded to the scene. The victim was airlifted to the nearest trauma center. On Sunday, September 8, 2013, the victim succumbed to his injuries, expiring at 5:37 a.m.

To prevent future occurrences of similar incidents, the following recommendations have been made:

Recommendation 1: Employers should ensure employees are using the correct equipment for the job.

Recommendation 2: Employers shall provide applicable appropriate worker safety training specific to the employee's job responsibilities.

Recommendation 3: Employers shall ensure that personal protective equipment (PPE) and special tools needed for work are provided, worn and used that are specific to their job responsibilities.

Recommendation 4: Employers should implement and enforce a drug-free workplace program to ensure their workers are not working impaired.

\section{$\underline{\text { Employer }}$}

The employer was a cable construction company with 10 employees. The company also performed work outside typical communications providers such as telephone and cable companies.

\section{Written Safety Programs and Training}


The company's written safety program did not have procedures/policies on tree trimming/clearing operations. The company did not verify the employee's safety training background since the victim had previously worked in this industry for two separate companies. The company's written worker safety program stated that employees were to be trained before starting work and that training records were to be maintained. However, there was no documentation of worker safety training.

\section{$\underline{\text { Victim }}$}

The victim was a 52-year-old father of four grown boys, who was employed with the company for three years. His occupation was a tree trimmer. The victim had been employed as a foreman for a tree trimming company for 10 years and as a DOT driver for another tree trimming company for one year previously. The victim was a high school graduate.

\section{Incident Scene}

The incident scene was located on a state highway in proximity to a two-lane bridge, which was located east of a county maintenance garage. The scene consisted of an open field with a telephone line in a wooded area next to a creek running parallel to the state highway.

\section{Weather}

The fall day was partly cloudy with temperatures ranging from 74-86 degrees Fahrenheit.

\section{$\underline{\text { Investigation }}$}

The Kentucky Fatality Assessment and Control Evaluation Program was notified of an occupational fatality involving a tree trimmer by the Kentucky Labor Cabinet.

On September 7, 2013 at 11:55 a.m., the company received a phone call from a supervisor about a tree overhanging a telephone line on a state highway. The company dispatched the victim and a coworker to remove the tree. They arrived on site at 12:10 p.m. and spoke with the landowner about accessing his property to cut down the tree. The landowner was concerned that a bucket truck might become stuck due to the wetness of the land and the recent rains, so the crew took their pickup truck to the location of the tree.

They arrived at the tree wearing their hardhats, but no gloves or safety glasses. They found the section of the tree resting on its stump and extending at an angle over the telephone line.

Normally, the line was approximately 20 to 25 feet above the ground and was supported by 30 foot poles. A broken section of the tree had contacted the telephone line between the poles and had pushed the line towards the ground, causing a considerable amount of tension on the line. The trunk of the trunk was 64 inches in height and approximately 3 feet in diameter. The section of the tree that was in contact with the line was the "fork" of the tree, two limbs extending out from the main trunk of the tree. The "fork" was 9 inches in diameter on the left fork and 11.5 inches in diameter on the right fork. 
Using a Stihl HT 101 Pole saw, the victim made two cuts on the right fork and a cut on the left fork. The victim made two more cuts on the left fork, but could not saw the tree limb all the way through. The victim set to the inside of the fork and attempted to make another cut on the left fork, when the pole saw became stuck. When the victim and a co-worker pulled on the pole saw, their hard hats to fell off, and they did not put them back on. The victim walked to the pickup truck and retrieved a Stilh MS 170 chain saw and sawed through the main trunk of the tree. When the victim made a cut through the tree trunk, the top forked section shifted, and the left fork section where the pole saw was stuck, fell and struck the victim. The limb section that struck the victim measured 9 feet in length and 10-12 inches in diameter.

The coworker stated that after the limb fell, he shouted to the victim, "Let's go" and received no response. The coworker did not see the tree limb strike the victim because he was back by the truck. The coworker walked to the area where the victim had been sawing the tree and found him unresponsive with the fork section on him, bleeding from his nose and mouth. The coworker called 911 and emergency crews responded to the scene. The victim was airlifted to the nearest trauma center. Sunday, September 8, 2013, 17 hours after the injury, the victim succumbed to his injuries expiring at 5:37 a.m.

The victim tested positive in the emergency room for cannabinoids and methamphetamines and it is unclear whether the presence of drugs played a role in this incident.

\section{Cause of Death}

The cause of death was herniation of the brain due to subdural hematoma, multiple blunt force trauma.

\section{$\underline{\text { Recommendations and Discussions }}$}

\section{Recommendation 1: Employers should ensure employees are using the correct equipment for the job.}

By using the correct equipment for the job, not only is it safer but it is more effective. A pole saw should never be used for this type of work. A pole saw is too small to handle the diameter of the tree they were cutting. A larger high-powered chain saw would be the appropriate equipment for this job.

A tree should never be cut above your head or shoulders with a chain saw. It is important to know that using a bucket truck to get above the tree would be the appropriate measure to take when removing large trees.

\section{Recommendation 2: Employers shall provide applicable appropriate worker safety training specific to the employee's job responsibilities.}

Due to the number of fatalities in the tree trimming occupational field, it is very important to be sure your employees are all properly trained. According to the OSHA standard 1910.268 (c) 
Telecommunication, employers shall provide training in various precautions and safe practices and ensure that employees do not engage in those activities until they have received proper training. According to 29 CFR 1910.268 (c), the training shall consist of on-the-job training or classroom type training or a combination of both. The employer shall certify employees have been trained by preparing a certification record which includes the identity of the person trained, the signature of the employer or the person who conducted the training, the date the training was completed and this shall be maintained on file for the duration of the employee's employment.

However, if an employer can certify the employee is already trained in the precautions and safe practices required by this standard, prior to his employment, training need not be provided but certification must be retained in the employees file. Training also shall include the recognition and avoidance of dangers relating to encounters with harmful substances, and animal, insect or plant life. First aid training and CPR shall also be included in this training.

The employer did not provide safety training to the victim because the employer assumed the victim had been trained to do the job because of the victim's previous employment with tree trimming companies. It's important to verify and certify employees the first day on the job. A copy of the victim's certification, and confirmation that he had been properly trained with previous companies, could have been obtained by a written request to the past employer. If no certification was available, then the employer needs to provide this training. The employer can go to the National Arborists website for information on arborist training and learning materials.

\section{Recommendation 3: Employers shall ensure that personal protective equipment (PPE) and special tools needed for work are provided and worn or used that are specific to their job responsibilities.}

Employers shall provide and ensure their employees are utilizing personal protective equipment for the job they are required to perform. The owner's manual on the Stihl MS 170 chain saw, page 5, states that operators are to wear head protection, eye/face protection, protective clothing and gloves as well as hearing protection. The employer provided hard hats for on-site work, however did not ensure they were being worn.

\section{Recommendation 4: Employers should implement and enforce a drug-free workplace program to ensure their workers are not working impaired.}

Employers who implement a drug-free workplace program with random drug testing can detect if employees are working under the influence of illegal drugs that cause them to be at risk for unsafe behaviors. Since the victim tested positive for illegal drugs in his system, this policy may have had an effect on whether the victim would have chosen to use the drugs while working or not.

\section{Keywords}

Tree Trimming

Training, 
Chain Saws

Pole Saws

Personal protective equipment

\section{References}

Stihl HT 100, 101, 130, 131. Stihl USA.

[http://www.stihlusa.com/WebContent/CMSFileLibrary/InstructionManuals/ht-100-101-130-

131-product-instruction-manual.pdf ] Accessed on: October 1, 2014.

Stihl MS 170, 180. Stihl USA.

[http://www.stihlusa.com/WebContent/CMSFileLibrary/InstructionManuals/STIHL-MS-170180-Product-Instruction-Manual.pdf] Accessed on: October 1, 2014.

Telecommunications. 29 CFR 1910.268.

First Aid. 29 CFR 1910.268 (c) (3).

[https://www.osha.gov/pls/oshaweb/owadisp.show_document?p_table=STANDARDS\&p_id=98

67] All accessed on: October 2, 2014.

Arborist Training Information. National Arborists.

[https://www.natlarb.com/html/arborist_training_information.html] Accessed on October 3, 2014.

\section{Further Reading:}

Electronic Code of Federal Regulations. [http://www.ecfr.gov/cgi-bin/textidx?SID=65b279ee2e7530009034c1f152d451e5\&tpl=/ecfrbrowse/Title29/29tab_02.tpl]

Accessed on October 5, 2014.

Tree Trimming Certification, Training Programs and Classes. Education Portal.

[http://education-

portal.com/articles/Tree_Trimming_Certification_Training_Programs_and_Classes.htmll Accessed on October 6, 2014.

eLearn- Interactive Online Learning Modules for Forest Management Practices. Southern Regional Extension Forestry. [http://elearn.sref.info/] Accessed on October 6,2014.

\section{Acknowledgements}

The Kentucky FACE program would like to thank the Kentucky Labor Cabinet and KY OSHA and Dave Leonard, consulting Arborist for their assistance with this report. 
The Kentucky Fatality Assessment \& Control Evaluation Program (FACE) is funded by grant 2U60OH008483-10 from the Centers for Disease Control and Prevention and the National Institute for Occupational Safety and Health. The purpose of FACE is to aid in the research and prevention of occupational fatalities by evaluating events leading to, during, and after a work related fatality. Recommendations are made to help employers and employees have a safer work environment. For more information about FACE and KIPRC, please visit our website: www.kiprc.uky.edu 


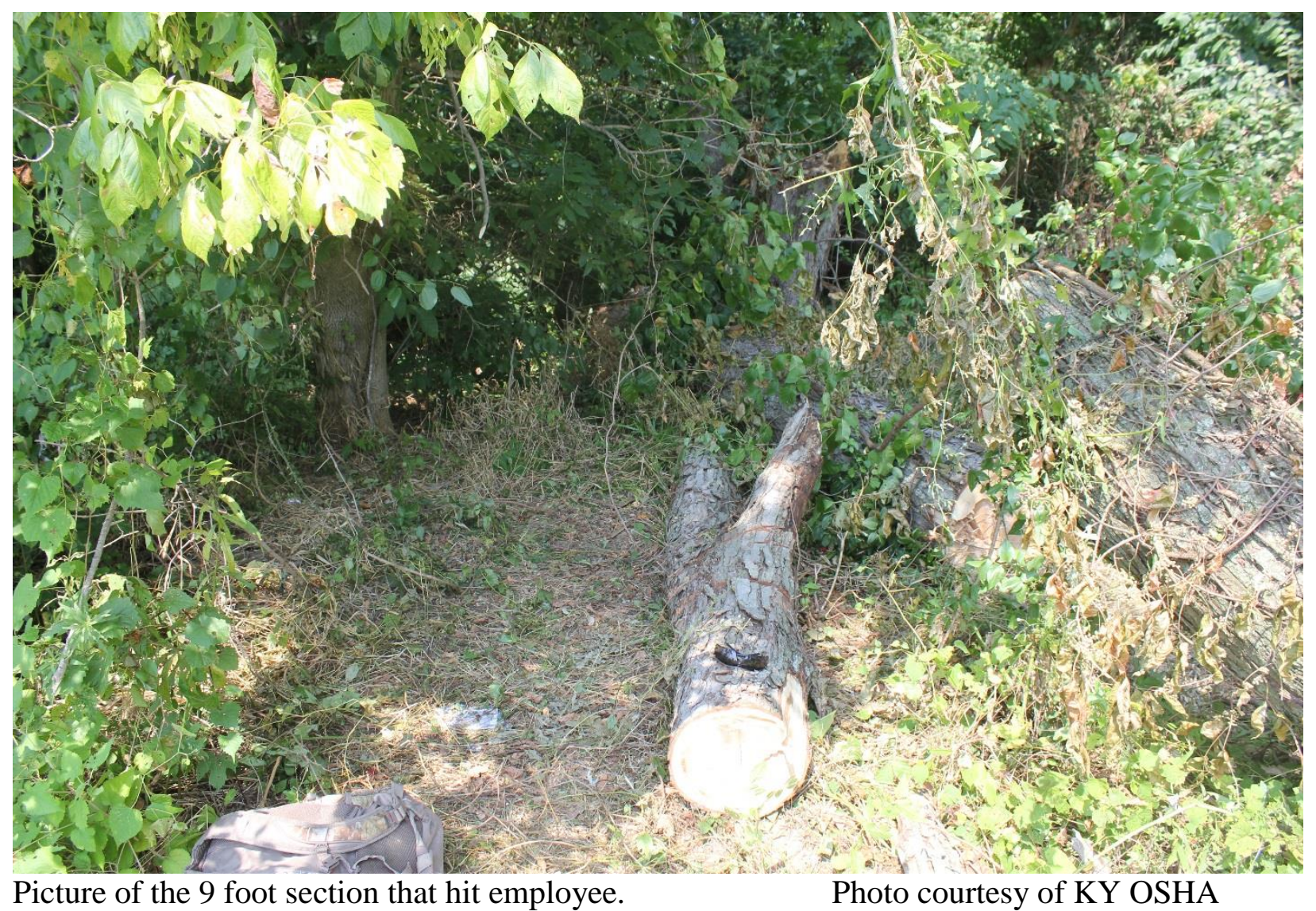




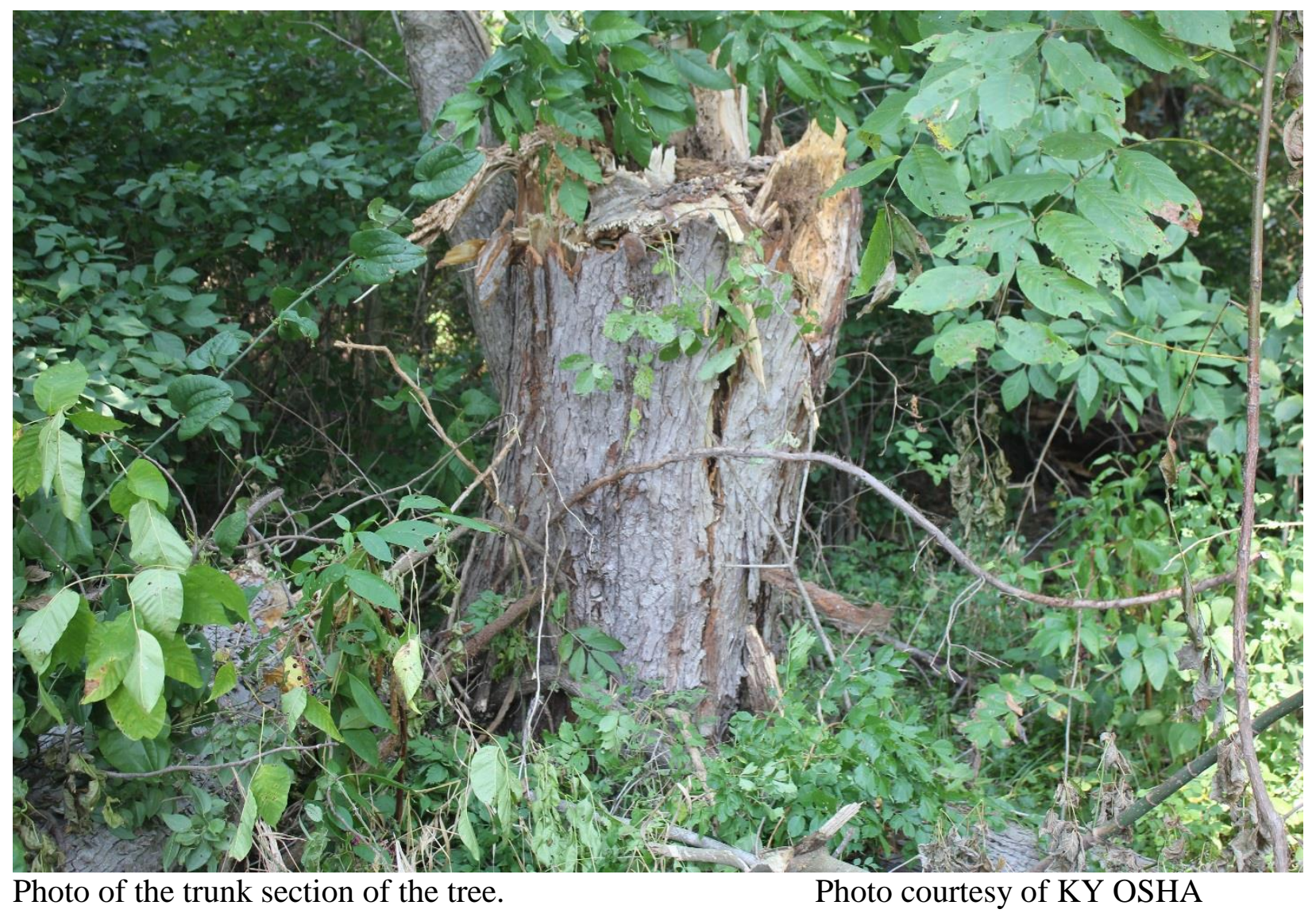




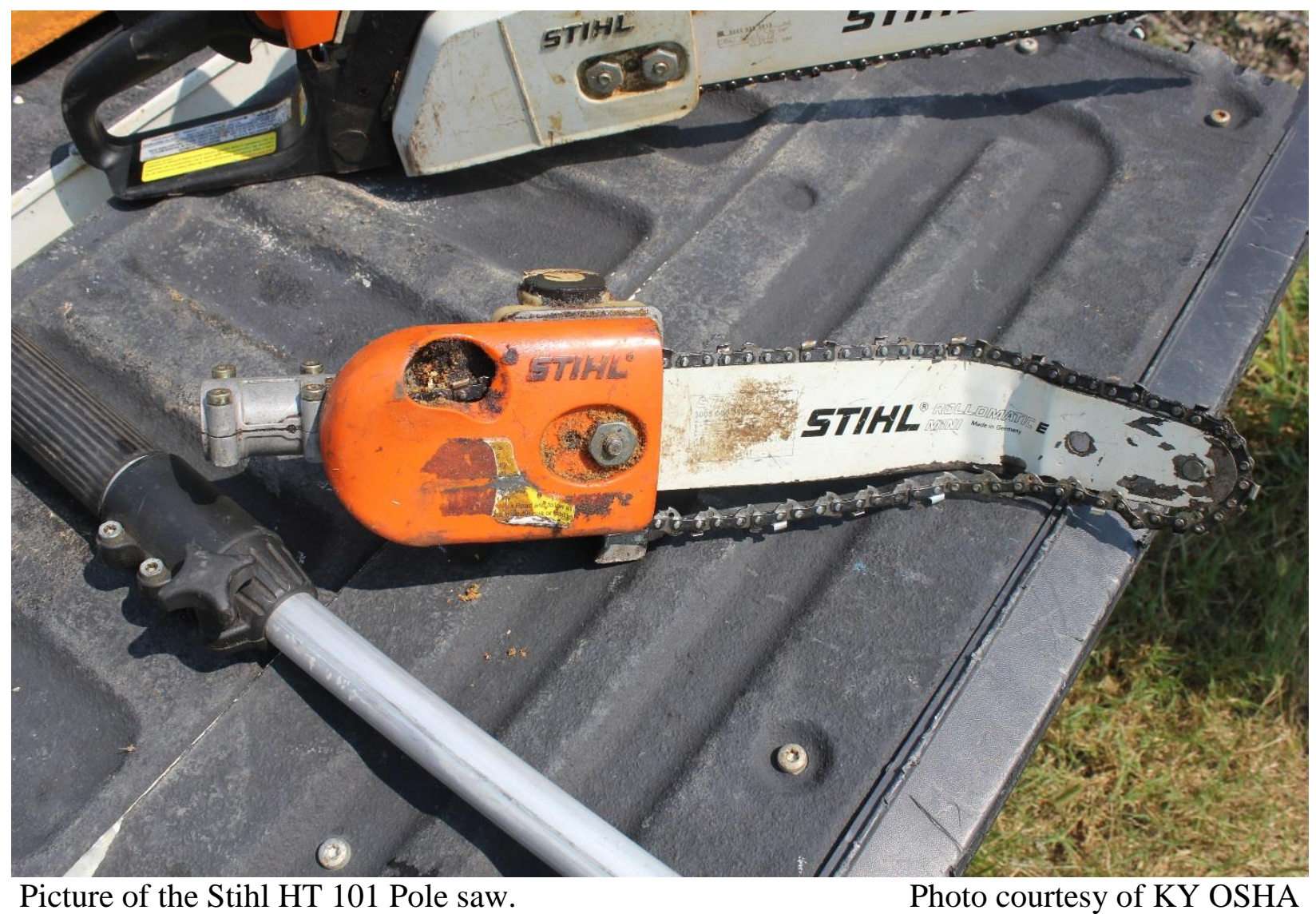

